ternary alloys together with the quaternary aluminium-copper-magnesium-silicon and aluminiummagnesium-silicon-manganese alloys; in one case, aluminium - zinc-magnesium - copper - manganese, a start has been made on a quinary series.

The work has most clearly justified the time and money expended on it, and this publication provides a first-rate summary of the results which have been obtained.

F. C. Thompson

\section{A RARE CRYPTOMERIA}

$\mathrm{Y}$

AKU-SHIMA, an island about thirty-seven miles off Kyushu, Japan, and covering approximately 190 square miles, is famed for the forests that cover its steep mountain-sides and for its abundant wildlife, especially deer and monkeys. The really unique and outstanding feature of the island, however, is the Cryptomeria japonica or 'Yaku-sugi' trees that are found there. These can be compared with the world's most spectacular trees, both because of their size-they grow to $16 \frac{1}{2} \mathrm{ft}$. in diameter and $117 \mathrm{ft}$. high -and their age, which is calculated to bo between 1,000 and 3,000 years old. Their classification in systematic botany is not clear, although they are believed to be the ancestors of the Japanese species of Cryptomeria, in spite of differing from them both morphologically and ecologically. At one time there seoms to have been a mysterious gap in the species' ecology, due either to its requirements or the conditions it was subjected to, as no trees are to be found between four hundred and eight hundred years old; they are all either older or younger. The Yaku-Shima virgin forests are of great interest, for the Yalku-sugi trees grow there along with firs, hemlock and Yamagurumas (Trochodendron aralioides, Sieb. et Zuce), and fill the island's valleys with tall trees decorated with intertwining epiphytic and parasitic plants.

At present, negotiations are going on between the Forestry Agency of the Ministry of Agriculture and Forestry and the National Park Division of the Ministry of Welfare to see whether the area should be designated as a national park. It would be a tragedy if the island's beauty were not perpetuated for future generations, and the International Union for the Protection of Nature has offered all possible help to its member, the National Parks Association of Japan, which in its turn is supporting the National Park Division's project (Bull. Inter. Union Protect. Nature, 4, Nos. 5 and 6; December 1955).

\section{WEATHER AND THE LAND}

$\mathrm{D}$

URING the early years of his period of office the late Sir Nelson Johnson, director of the meteorological Office during 1938-53, realized that much greater assistance could and should be given by the Office to the economic life of Great Britain. One of his major decisions in this respect was the establishment in 1947 of the Agricultural Meteorological Section of the Climatology Branch, the Section becoming in 1948 the Agricultural Branch of the Office under the assistant director for climatology. Since then the Branch has developed its activities very widely. Besides the Branch office at the headquarters of the Meteorological Office, there are now meteorological advisers at the offices in Bristol and
Cambridge of the National Advisory Service for Agriculture, and a meteorologist has recently been posted to the Meteorological Office, Edinburgh, for similar duties in Scotland.

A pamphlet written by the staff of the Branch* explains to the farmer the 'why and how' of his meteorological problems, how meteorologists can help to solve the problems, and how best to use the forecasts prepared at the Central Forecast Office and broadcast by the B.B.C.

The first chapter describes the general climate of the British Isles with special reference to plant growth, and the second gives the local variations in climate associated with altitude, aspect, and the nature of the soil and its covering. The third chapter explains the meteorological aspects of methods available for using solar radiation more efficiently by means of glasshouses and cloches, and methods such as shelterbelts and irrigation, of mitigating unfavourable meteorological effects. After this is a chapter describing the structure of depressions and the use of cloud forms and other portents of weather in interpreting the broadcast forecasts and applying them to local conditions. Finally, the fifth chapter gives the times of and areas used in the broadcast forecasts, lists the local meteorological offices from which forecasts can be obtained by telephone and the various special forecast services such as spell warnings which are available, defines terms used in weather forecasts, and states how the farmer can obtain advice (from headquarters, or from the meteorological offices attached to the National Advisory Service or to the Edinburgh Meteorological Office) on making the best use of his land.

The pamphlet gives a general compendium of meteorological knowledge as applied to agriculture in all its aspects and is of very great value to all agriculturists, while the parts on the use of the broadcast forecasts would be of much value to those whose business or pleasure is affected by the weather. Chapter 4 could well be used in schools for teaching the use of weather forecasts.

* Bulletin No. 165 of the Ministry of Agriculture. Fisheries and Food: Weather and the Land. Pp. iv $+35+4$ plates. (London: H.M.S.O., 1955.) 3s. net.

\section{EMPLOYMENT STATISTICS FOR RECENT BRITISH GRADUATES}

A

RECENT broadsheet on "Graduates' Jobs", issued by Political and Economic Planning (No. 387), summarizes the results of an inquiry into the careers of 3,961 men who graduated in Great Britain in 1950. Returns were received from some 30 per cent of these, and it is unlikely that there is any main source of bias in the sample; more than half graduated in arts, more than a quarter in science, and less than one-fifth in technology. Many were older than the normal run of graduates, and most had seen war service or had done national service before going to a university. More than half had married by October 1954, and 20 per cent had married in the year they graduated or earlier.

Much the largest entries were into industry and teaching (both 23.4 per cent), mathematics and science teaching claiming 6.7 per cent, while 33 per cent of arts graduates became teachers as compared with 19.9 per cent of science graduates. The Civil Service took 8.6 per cent, 5.5 per cent (or 15.7 per 